\title{
ACESSO Ã INFORMAÇÃO: TRAÇANDO UM PANORAMA DA LEI 12.527/2011 A PARTIR DE UMA REVISÃO SISTEMÂTICA DE LITERATURA
}

ACCESS TO INFORMATION: TRACING A PANORAMA OF LAW 12.527/2011 FROM A SYSTEMATIC LITERATURE REVIEW

\section{Jovino Pinto Filho}

Mestrando em Administração Pública pela Universidade Federal de Alagoas (Maceió/Brasil). Administrador na Universidade Federal de Alagoas (Maceió/Brasil).

E-mail: jovinoadm@gmail.com

\section{Andrew Beheregarai Finger}

Doutor em Administração pela Universidade do Vale do Rio dos Sinos (São Leopoldo/Brasil). Professor na Universidade Federal de Alagoas (Maceió/Brasil).

E-mail: finger.andrew@gmail.com

\section{Ibsen Mateus Bittencourt Santana Pinto}

Doutor em Administração de Empresas pela Universidade Presbiteriana Mackenzie (São Paulo/Brasil).

Professor na Universidade Federal de Alagoas (Maceió/Brasil).

E-mail: ibsen.ead@gmail.com 


\section{RESUMO}

A Constituição Federal brasileira garante, desde o ano de 1988, o direito de acesso às informações públicas, contudo, apenas em 2011 foi promulgada lei que regulamentou este direito. A Lei № 12.527/2011 gerou mudanças no comportamento da administração pública, o que propiciou pesquisas a este respeito. Nesse sentido, este artigo teve como objetivo apresentar um panorama dos estudos que tiveram como base a Lei de Acesso à Informação - LAl, mediante revisão sistemática de literatura, dentro de uma abordagem quantiqualitativa. Para tanto, utilizou-se as bibliotecas eletrônicas Spell e Scielo, nas quais foram encontrados 45 artigos sobre a LAI. Os resultados destacam pesquisas voltadas à aplicação da lei na esfera do Poder Executivo Municipal, do Poder Executivo Federal, além de obras que discutiram a lei e sua contribuição para o país. Frente à crescente quantidade de artigos produzidos por pesquisadores de diversos campos de conhecimento e do número de órgãos e entidades analisadas, observa-se progressivo interesse pelo tema e sua grande possibilidade de exploração.

Palavras-chave: Lei nº 12.527/2011. LAl. Acesso à Informação. Transparência.

\section{ABSTRACT}

The Brazilian Federal Constitution guarantees, since 1988, the right of access to public information, however, only in 2011 was a law enacted that regulated this right. Law $N^{0}$. 12.527/2011 generated changes in the behavior of public administration, which led to research in this regard. This article aimed to present an overview of studies based on the Brazilian Access to Information Law, by means of a systematic review of literature, within a quantitative and qualitative approach. For this purpose, the electronic libraries Spell and Scielo were used, in which 45 articles on the law were found. The results highlight research aimed at law enforcement in the sphere of the Municipal Executive Branch, the Federal Executive Branch, and works that discussed the law and its contribution to the country. In view of the growing number of articles produced by researchers from different fields of knowledge, and the number of public bodies analysed, there is a progressive interest in the subject and its great possibility of exploration.

Keywords: Law n 12.527/2011. LAl. Access to information. Transparency. 


\section{INTRODUÇÃO}

O direito à informação, no Brasil, tem como base constitucional o artigo 5, inciso XXXIII, o qual versa que todos têm direito a receber dos órgãos públicos informações de seu interesse particular, ou de interesse coletivo, que serão prestadas no prazo da lei, ressalvadas aquelas cujo sigilo seja imprescindivel à segurança da sociedade e do Estado (BRASIL, 1988). O referido artigo foi regulamentado mediante a Lei 12.527/2011 - Lei de Acesso à Informação (LAI), e pelo Decreto n 7.724/2012, ambos tratam especificamente do direito à informação.

A construção da LAl e de outras leis, a exemplo da Lei Complementar no 101/2000 - Lei de Responsabilidade Fiscal (LRF) e da Lei Complementar n 131/2009 - Lei da Transparência, demonstra que o Estado, ao longo do período pós-constitucional, buscou se estabelecer como um Estado democrático e passou a criar mecanismos que possibilitaram maior transparência em suas ações. Comportamento distinto do que ocorria na fase patrimonialista da administração brasileira, na qual a informação era circunscrita a poucos e direcionada a interesses privados, favorecendo a corrupção e o consequente descrédito do Estado (ROSA et al., 2016).

A transparência tem como objetivo garantir, a cada cidadão interessado, o acesso às informações que possibilitem verificar o desempenho dos governantes (VISENTINI; SANTOS, 2019) e, para isso, tais informações precisam estar disponibilizadas de forma que possam ser localizadas facilmente, com agilidade, em formato passível de verificação, linguagem clara e compreensível (DREHMER; RAUPP, 2018). Com transparência e a garantia de acesso à informação de qualidade, torna-se possivel consolidar um cenário de gestão participativa (CARNIELLO; SANTOS; OLIVEIRA, 2011) e de accountability (PAPENFUB; SCHAEFER, 2010) que, no entendimento de Abrucio e Loureiro (2004), é um termo que pode ser entendido como o processo de responsabilização dos governantes pelos seus atos e omissões.

Faz-se necessário, então, que o Estado crie regulamentos que direcionem os órgãos públicos a fornecerem informações de maneira organizada e com qualidade, o que leva a compreender que a legislação que trata a respeito do acesso às informações públicas pode ser encarada como propulsora da transparência, participação e da accountability.

Assim, diante da significância da Lei de Acesso à Informação para a sociedade, o presente estudo se propôs a responder o seguinte questionamento: Qual o panorama da produção acadêmica brasileira a respeito da Lei 12.527/2011? No intento de elucidar essa questão, o objetivo desta pesquisa foi o de analisar os estudos que tiveram como base de construção a Lei de Acesso à Informação brasileira.

O presente artigo foi constituído sob o modelo de revisão sistemática, em que foram analisados artigos publicados nas bibliotecas eletrônicas on-line Scielo (Scientific Electronic Library On-line) e Spell 
(Scientific Periodicals Electronic Library), delineando-se detalhes das publicações encontradas, tais como seus títulos, autores, identificação de obras e autores referenciados, da metodologia utilizada, detalhes dos periódicos em que os estudos foram publicados, verificação de subtemas e suas formas de abordagem, além de outras informações relevantes das publicações produzidas desde o ano de criação da lei, 2011, até 2019.

Ao atingir o objetivo almejado, o estudo demonstra relevância por apresentar à academia um panorama das publicações existentes no país a respeito da temática proposta. Esse resultado fornece subsídios para que pesquisadores compreendam como ocorreu o desenvolvimento das discussões sobre a LAl, o que possibilita a identificação de lacunas e a criação de novas propostas, ideias e estratégias de pesquisa, de forma a ampliar a capacidade de aprofundamento e agregação de valor ao assunto em questão.

Este trabalho é composto de cinco seções, estruturando-se a partir desta introdução. A seção seguinte apresenta o referencial teórico sobre a Lei de Acesso à Informação, em que são abordadas as suas características e importância; por conseguinte, a seção 3 apresenta os procedimentos metodológicos utilizados para o encontro dos objetivos da pesquisa; na seção 4 é discutida a análise dos resultados da revisão sistemática; e, por fim, a seção 5 apresenta as considerações finais do estudo.

\section{LEI DE ACESSO À INFORMAÇÃO}

A Lei 12.527, de 18 de novembro de 2011, conhecida como Lei de Acesso à Informação - LAl, foi implementada pela administração pública federal e regulamentada com o Decreto $n^{\circ} 7.724$, de 16 de maio de 2012, como um instrumento para que as necessidades de informação dos cidadãos se tornassem acessíveis e facilitadas, propiciando mecanismos que permitem a pessoas físicas ou jurídicas, independentemente de motivação, receberem informações de seu interesse pelos órgãos públicos (MACIEL et al., 2019). Para tanto, a administração pública deve gerir a documentação governamental de forma a franquear sua consulta a todos os que dela necessitem, podendo utilizar sítios virtuais oficiais como ferramenta de divulgação e pesquisa (SILVA NETO, et al., 2019).

Suas regras devem ser implementadas por toda a administração pública por se tratar de lei de caráter nacional, bem como, no que couber, as entidades privadas sem fins lucrativos que recebam recursos públicos diretamente do orçamento ou mediante subvenções sociais, contrato de gestão, termo de parceria, convênios, acordo, ajustes ou outros instrumentos congêneres (BRASIL, 2011).

As diretrizes de acesso à informação da LAl subdividem-se em dois eixos: transparência ativa e transparência passiva. A transparência ativa refere-se ao dever que a administração pública tem em 
promover, independente de requerimentos, informações em seus sítios virtuais da internet. Por seu turno, a transparência passiva ocorre mediante Serviço de Informações ao Cidadão (SIC), setor que deve ser criado em todos os órgãos submetidos à LAl para receber, encaminhar e fornecer respostas às solicitações de informações formalizadas pelos cidadãos (SILVA; EIRÃO; CAVALCANTE, 2013).

Da forma que se apresenta, a Lei 12.527/2011 pressupõe uma lógica político-jurídica de acesso à informação inserindo o cidadão e suas necessidades no epicentro dela (JARDIM, 2012), tendo potencial para promover uma mudança na cultura existente no Estado, fazendo com que os agentes públicos se conscientizem de que não são eles os detentores das informações, mas sim, o cidadão (BARROS; MEDLEG, 2018).

A Lei 12.527/2011 consolida-se, então, como um marco da transparência e do controle social sobre o Estado ao promover ganhos de qualidade na prestação do serviço público por ter o dever de informar, de modo entendível, sobre o uso de recursos públicos e prestar contas de seus atos, o que possibilita um avanço no que se refere à participação cívica, que passa a poder acompanhar e fiscalizar o poder público (CARVALHO; FREITAS; BARBOSA, 2019; VIANNA JUNIOR, et al., 2019).

\section{METODOLOGIA}

De forma a alcançar o objetivo proposto, esta pesquisa utilizou a abordagem mista, por empregar características da pesquisa quantitativa, na quantificação e tratamento dos dados obtidos nos artigos analisados, bem como qualitativa, ao se permitir analisar e interpretar dados descritivos e interativos, procurando compreender o problema em questão (CRESWELL, 2007; RICHARDSON, 2012). A condução do estudo ocorreu mediante revisão sistemática de literatura com base em Tranfield, Denyer e Smart (2003), Sampaio e Mancini (2007), Galvão e Pereira (2014), contando com as seguintes fases: definição da questão científica; identificação da base de dados; estabelecimento de critérios para seleção dos artigos; condução da busca nas bases de dados escolhidas; definição da seleção inicial de artigos; aplicar os critérios de seleção dos artigos e justificar exclusões; analisar os estudos; sintetizar as informações dos artigos e preparar um resumo crítico; e, por fim, apresentação da conclusão.

Procedeu-se à busca de artigos referentes à Lei de Acesso à Informação, publicados desde o ano de 2011 - ano de sua criação, sendo selecionados aqueles que avaliaram o cumprimento da lei em algum órgão ou entidade pública, o papel de alguns órgãos para a implementação da lei, além dos artigos teóricos que dissertaram sobre os aspectos sociais e/ou políticos da referida legislação, de forma a apresentar aos leitores sob quais perspectivas a temática foi tratada ao longo dos últimos anos. 


\section{Gestãoe \\ Desenvolvimento}

e-ISSN: 2446-6875

p-ISSN: $1807-5436$

A coleta de dados ocorreu por meio das bibliotecas eletrônicas on-line Scielo e Spell, utilizando-se o cruzamento das seguintes palavras-chave: "Lei de acesso à informação"; "Lei 12.527"; "Lei 12.527/2011". Não foram observadas alterações na busca por palavras separadamente e conectadas com a função "and", disponível no campo de busca avançada das bibliotecas eletrônicas. Foram identificados 37 artigos na base Spell, dos quais foram selecionados 31, enquanto na base Scielo foram encontrados 52 artigos, sendo 18 os selecionados. Os artigos descartados ou não abordavam a lei brasileira ou apenas a mencionava, o que não coaduna com o enfoque principal do estudo em tela. Após a seleção, foram comparados os artigos das duas citadas bibliotecas, observando-se 04 repetições, o que resultou na seleção final de 45 estudos.

Nas publicações selecionadas analisaram-se os seguintes aspectos: ano e periódico de publicação; classificação Qualis/CAPES; título da obra; quantidade de periódicos por Qualis/CAPES; evolução do quantitativo de publicações; quantidade de autores por estudo e os mais relevantes; obras mais mencionadas, seus autores e quantidade de citações; autores principais mais mencionados e suas ocupações; o detalhamento dos procedimentos metodológicos e, por fim, categorização de subtemas, sua quantificação e principais abordagens.

\section{RESULTADOS E DISCUSSÃO}

Esta seção apresenta as análises obtidas consoante o procedimento metodológico desenvolvido. No quadro 1, observa-se o ano de publicação das 45 obras, o periódico em que foi lançada, a classificação Qualis dele e o título do artigo.

Quadro 1 - Lista de artigos por ano, periódico, Classificação Qualis e título da obra

\begin{tabular}{|c|c|c|c|}
\hline No & $\begin{array}{c}\text { Ano de publi- } \\
\text { cação }\end{array}$ & Periódico & Título do Artigo \\
\hline 1 & 2011 & $\begin{array}{c}\text { Revista do Serviço Pú- } \\
\text { blico }\end{array}$ & $\begin{array}{r}\text { A construção da Lei de Acesso à Informação Pública no Brasil: de- } \\
\text { safios na implementação de seus princípios }\end{array}$ \\
\hline 2 & 2012 & $\begin{array}{c}\text { Desenvolvimento em } \\
\text { questão }\end{array}$ & $\begin{array}{c}\text { Acesso à informação e ação Comunicativa: Novo Trunfo para a Ges- } \\
\text { tão Social }\end{array}$ \\
\hline 3 & 2012 & Estudos históricos & $\begin{array}{c}\text { Direito à informação e direito à vida privada: os impasses em torno } \\
\text { do acesso aos arquivos da ditadura militar brasileira }\end{array}$ \\
\hline 5 & 2013 & $\begin{array}{c}\text { Cadernos de saúde } \\
\text { pública }\end{array}$ & Lei de acesso à informação, privacidade e a pesquisa em saúde \\
\hline
\end{tabular}




\section{Gestãoe \\ Desenvolvimento}

\begin{tabular}{|c|c|c|c|}
\hline 6 & 2013 & $\begin{array}{l}\text { Revista evidenciação } \\
\text { contábil \& finanças }\end{array}$ & $\begin{array}{l}\text { Transparência dos municípios do Rio Grande do Norte: avaliação } \\
\text { da relação entre o nível de disclosure, tamanho e características } \\
\text { socioeconômicas }\end{array}$ \\
\hline 7 & 2013 & Revista Direito GV & Transparência pública e a atuação normativa do CNJ \\
\hline 8 & 2014 & $\begin{array}{l}\text { Pensamento \& Reali- } \\
\text { dade }\end{array}$ & $\begin{array}{l}\text { Lei de Acesso a Informação: uma leitura da implementação do Ins- } \\
\text { tituto Federal do Rio Grande do Norte }\end{array}$ \\
\hline 9 & 2014 & Sequência & $\begin{array}{l}\text { O Direito ao Acesso à Informação na Construção da Democracia } \\
\text { Participativa: uma análise da página do Conselho Nacional de Justi- } \\
\text { ça no Facebook }\end{array}$ \\
\hline 10 & 2014 & $\begin{array}{c}\text { Revista do Serviço Pú- } \\
\text { blico }\end{array}$ & O papel das ouvidorias na comunicação pública do Poder Judiciário \\
\hline 11 & 2014 & Gestão e Planejamento & $\begin{array}{l}\text { Prestação de contas nos portais eletrônicos de Assembléias Legis- } \\
\text { lativas: um estudo após a Lei de acesso à informação }\end{array}$ \\
\hline 12 & 2014 & $\begin{array}{l}\text { Revista do Serviço Pú- } \\
\text { blico }\end{array}$ & $\begin{array}{l}\text { Transparência, monitoramento e avaliação de programas no Brasil: } \\
\text { em busca de opacidades que podem restringir o exercício do con- } \\
\text { trole social }\end{array}$ \\
\hline 13 & 2015 & Cadernos EBAPE.BR & $\begin{array}{l}\text { O papel das controladorias locais no cumprimento da Lei de Acesso } \\
\text { à Informação pelos municípios brasileiros }\end{array}$ \\
\hline 14 & 2015 & $\begin{array}{l}\text { Perspectivas em Ciência } \\
\text { da Informação }\end{array}$ & $\begin{array}{l}\text { Privacidade do usuário na atividade de busca: o caso do Arquivo } \\
\text { Público do Estado de São Paulo }\end{array}$ \\
\hline 15 & 2015 & Contexto & $\begin{array}{l}\text { Prestação de contas no legislativo local antes e depois da Lei de } \\
\text { acesso à informação }\end{array}$ \\
\hline 16 & 2015 & $\begin{array}{l}\text { Cadernos Gestão Públi- } \\
\text { ca e Cidadania }\end{array}$ & $\begin{array}{l}\text { Avaliação de sítios municipais da Região Metropolitana da Grande } \\
\text { Vitória-ES }\end{array}$ \\
\hline 17 & 2015 & $\begin{array}{l}\text { Revista Amazônia, or- } \\
\text { ganizações e sustenta- } \\
\text { bilidade }\end{array}$ & $\begin{array}{l}\text { Análise normativa da transparência em um Tribunal de Contas dos } \\
\text { municípios }\end{array}$ \\
\hline 18 & 2015 & $\begin{array}{l}\text { Revista administração } \\
\text { pública }\end{array}$ & $\begin{array}{l}\text { Ranking das prefeituras da região Sul do Brasil: uma avaliação a } \\
\text { partir de critérios estabelecidos na Lei de Acesso à Informação }\end{array}$ \\
\hline 19 & 2016 & TransInformação & $\begin{array}{l}\text { Transparência e acesso à informação: um estudo da demanda por } \\
\text { informações contábeis nas universidades federais brasileiras }\end{array}$ \\
\hline 20 & 2016 & $\begin{array}{l}\text { Revista de investiga- } \\
\text { ções constitucionais }\end{array}$ & $\begin{array}{l}\text { Princípios sobre o direito de acesso à informação oficial na América } \\
\text { Latina }\end{array}$ \\
\hline 21 & 2016 & $\begin{array}{l}\text { Revista Administração } \\
\text { em Diálogo - RAD }\end{array}$ & $\begin{array}{l}\text { Planejamento Governamental e Acesso à Informação no Brasil: } \\
\text { Lacunas, Complementariedade e Mudança Institucional }\end{array}$ \\
\hline 22 & 2016 & Interface & $\begin{array}{l}\text { O direito de acesso à informação pública e a gestão da informação } \\
\text { nas universidades: estudo de caso em uma instituição pública de } \\
\text { ensino superior }\end{array}$ \\
\hline
\end{tabular}




\section{Gestãoe \\ Desenvolvimento}

\begin{tabular}{|c|c|c|c|}
\hline 23 & 2016 & $\begin{array}{l}\text { Revista catarinense da } \\
\text { Ciência Contábil }\end{array}$ & $\begin{array}{c}\text { Disclosure no serviço público: análise da aplicabilidade da Lei de } \\
\text { transparência em municípios mineiros }\end{array}$ \\
\hline 24 & 2016 & $\begin{array}{l}\text { Revista catarinense da } \\
\text { Ciência Contábil }\end{array}$ & $\begin{array}{l}\text { A transparência ativa nos municípios de Santa Catarina: avaliação } \\
\text { do índice de atendimento à Lei de acesso à informação e suas de- } \\
\text { terminantes }\end{array}$ \\
\hline 25 & 2016 & $\begin{array}{l}\text { Navus revista de gestão } \\
\text { e tecnologia }\end{array}$ & $\begin{array}{l}\text { A Lei de Acesso à Informação como instrumento de controle social: } \\
\text { diagnóstico dos municípios do sul do Brasil à luz do artigo } 8^{\circ} \text { da lei } \\
\qquad 12527 / 2011\end{array}$ \\
\hline 26 & 2017 & $\begin{array}{l}\text { Desenvolvimento em } \\
\text { questão }\end{array}$ & $\begin{array}{l}\text { Transparência do Legislativo Local à Luz da Lei de Acesso à Infor- } \\
\text { mação: Evidências Empíricas a Partir dos maiores municípios Bra- } \\
\text { sileiros }\end{array}$ \\
\hline 27 & 2017 & $\begin{array}{l}\text { Perspectivas em Ciência } \\
\text { da Informação }\end{array}$ & $\begin{array}{l}\text { Governo eletrônico no Rio Grande do Norte: uma avaliação de pre- } \\
\text { feituras municipais a partir de lei de acesso à informação }\end{array}$ \\
\hline 28 & 2017 & Gestão.org & $\begin{array}{l}\text { Uma Análise dos Pedidos de Acesso à Informação Encaminhados a } \\
\text { uma Instituição de Ensino Superior }\end{array}$ \\
\hline 29 & 2017 & $\begin{array}{l}\text { Desenvolvimento em } \\
\text { questão }\end{array}$ & $\begin{array}{l}\text { Análise do Grau de Aderência à Lei de Responsabilidade Fiscal e à } \\
\text { Lei de Acesso à Informação nos Municípios do Estado do Rio Gran- } \\
\text { de do Sul com Mais de } 50 \text { Mil Habitantes }\end{array}$ \\
\hline 30 & 2018 & $\begin{array}{l}\text { Revista de Contabili- } \\
\text { dade do mestrado em } \\
\text { Ciências Contábeis da } \\
\text { UERJ }\end{array}$ & $\begin{array}{l}\text { Transparência governamental: uma análise bibliométrica e socio- } \\
\text { métrica de periódicos internacionais }\end{array}$ \\
\hline 31 & 2018 & Revista Direito GV & $\begin{array}{l}\text { Os desafios da Administração Pública na disponibilização de dados } \\
\text { sensíveis }\end{array}$ \\
\hline 32 & 2018 & $\begin{array}{l}\text { Administração Pública e } \\
\text { Gestão Social }\end{array}$ & $\begin{array}{c}\text { Elaboração de um ranking da transparência e compreensão das } \\
\text { práticas de gestão de municípios integrantes do COREDE Missões- } \\
\text {-RS }\end{array}$ \\
\hline 33 & 2018 & $\begin{array}{l}\text { Revista de Administra- } \\
\text { ção Pública }\end{array}$ & $\begin{array}{l}\text { Da opacidade à transparência? Avaliando a Lei de Acesso à Infor- } \\
\text { mação no Brasil cinco anos depois }\end{array}$ \\
\hline 34 & 2018 & $\begin{array}{l}\text { Sociedade, Contabilida- } \\
\text { de e Gestão }\end{array}$ & $\begin{array}{l}\text { Comparando Transparência Passiva na esfera estadual: Executivo, } \\
\text { Legislativo e Judiciário }\end{array}$ \\
\hline 35 & 2018 & Estudos Avançados & Como salvar a política? \\
\hline 36 & 2018 & $\begin{array}{l}\text { Perspectivas em Ciência } \\
\text { da Informação }\end{array}$ & $\begin{array}{l}\text { Acesso à informação na região nordeste: balanço da criação da LAI } \\
\text { nos estados e o processo de sua regulamentação no Maranhão }\end{array}$ \\
\hline 37 & 2018 & Biblios & A Lei de Acesso à Informação e a gestão de documentos \\
\hline 38 & 2018 & $\begin{array}{l}\text { Revista Eletrônica Cien- } \\
\text { tífica do CRA-PR }\end{array}$ & $\begin{array}{c}\text { A adequação das Instituições Federais de Ensino Superior gaúchas } \\
\text { à Lei de acesso à informação }\end{array}$ \\
\hline 39 & 2019 & Pretexto & Tecnologia da informação como apoio à participação social \\
\hline
\end{tabular}




\section{Gestãoe \\ Desenvolvimento}

e-ISSN: 2446-6875

p-ISSN: 1807-5436

\begin{tabular}{|c|c|c|c|}
\hline 40 & 2019 & $\begin{array}{l}\text { Teoria e Prática em } \\
\text { Administração }\end{array}$ & $\begin{array}{l}\text { Transparência Fiscal dos Municípios Mais Populosos do Estado de } \\
\text { Pernambuco }\end{array}$ \\
\hline 41 & 2019 & $\begin{array}{l}\text { Revista eletrônica de } \\
\text { Administração }\end{array}$ & $\begin{array}{l}\text { Proposta de índice bidimensional de transparência da informação } \\
\text { público-eletrônica como ferramenta para participação e controle } \\
\text { sociais }\end{array}$ \\
\hline 42 & 2019 & $\begin{array}{l}\text { Revista de Gestão e } \\
\text { Secretariado }\end{array}$ & $\begin{array}{l}\text { O acesso à informação na gestão pública: dificuldades enfrentadas } \\
\text { pelo poder executivo municipal de Londrina (PR) }\end{array}$ \\
\hline 43 & 2019 & Gestão e Planejamento & $\begin{array}{l}\text { Assembleias Legislativas da região nordeste: um estudo sobre a Lei } \\
\text { de acesso à informação }\end{array}$ \\
\hline 44 & 2019 & $\begin{array}{l}\text { Sociedade, Contabilida- } \\
\text { de e Gestão }\end{array}$ & $\begin{array}{l}\text { A Percepção dos Observatórios Sociais sobre a Qualidade, Utilidade } \\
\text { e Suficiência da Transparência Pública dos Municípios Brasileiros }\end{array}$ \\
\hline 45 & 2019 & $\begin{array}{l}\text { Perspectivas em Ciência } \\
\text { da Informação }\end{array}$ & $\begin{array}{c}\text { Sistema Eletrônico do Serviço de Informação ao Cidadão (e-SIC) e } \\
\text { sua contribuição para a transparência: uma experiência gerencial } \\
\text { em uma universidade federal }\end{array}$ \\
\hline
\end{tabular}

\section{Fonte: Elaborado pelos autores}

Foram identificados 33 periódicos nacionais que publicaram artigos sobre a Lei de Acesso à Informação. Entre os que tiveram maior número de publicações destacam-se: Revista Perspectivas em Ciência da Informação (05 publicações); Revista do Serviço Público, Revista Desenvolvimento em Questão (03 publicações, cada); Revista Direito GV, Revista Catarinense da Ciência Contábil, Revista Gestão e Planejamento e Revista Sociedade, Contabilidade e Gestão (02 publicações, cada). Os demais periódicos elencados tiveram apenas uma publicação sobre a temática estudada, entre os anos de 2011 e 2019.

No que tange à classificação Qualis, elaborada pela Coordenação de Aperfeiçoamento de Pessoal de Nivel Superior - CAPES, entende-se que os extratos A1 e A2 são considerados de excelência e o B1 se refere às publicações de maior qualidade (BARATA, 2016). Nessa perspectiva, observa-se que houve apenas 36\% de publicações nas revistas com maior conceito, sendo predominante a publicação em revistas com conceito B2, como observado na Tabela 1.

Tabela 1 - Quantidade de periódicos por Qualis/CAPES

\begin{tabular}{ccc}
\hline QUALIS/CAPES & Quantidade & Percentual \\
\hline A1 & 1 & $2,2 \%$ \\
A2 & 5 & $11,1 \%$ \\
B1 & 10 & $22,2 \%$ \\
B2 & 20 & $44,4 \%$ \\
B3 & 7 & $15,6 \%$ \\
B4 & 2 & $4,4 \%$ \\
\hline
\end{tabular}

Fonte: Elaborado pelos autores 
Cumpre ressaltar que os extratos selecionados foram os da área de avaliação "Administração, Ciências Contábeis e Turismo" e, nos casos em que a revista não possuía classificação nessa área, utilizouse a área de avaliação "interdisciplinar" levando-se em consideração a diversidade de campos de estudo que tratam o tema, como a Ciência da Informação, Comunicação, Direito, História, entre outras, o que demonstra sua interdisciplinaridade.

Quanto à evolução quantitativa de publicações, a Figura 1 mostra que até o ano de 2016 a quantidade de publicações sobre a Lei de Acesso à Informação era crescente, tendo revertido essa tendência no ano de 2017. Em 2018, por sua vez, ocorreu a maior quantidade de publicações até então, 09, voltando a ocorrer menos publicações em 2019.

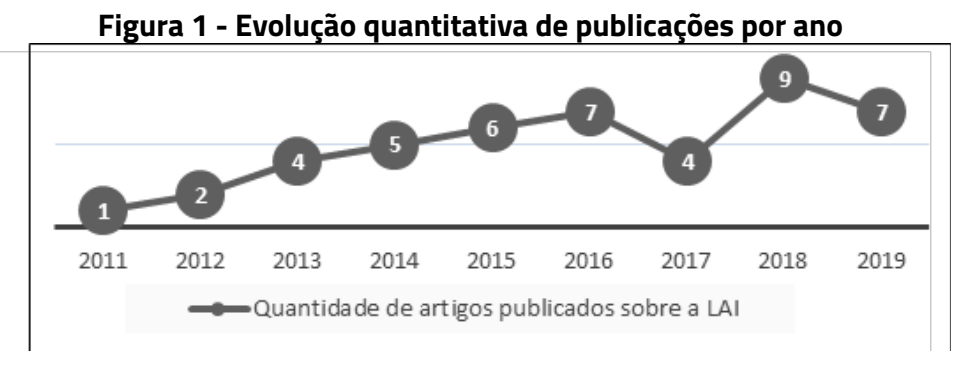

Fonte: Elaborado pelos autores

As publicações analisadas possuem entre 01 e 05 autores. 0 maior percentual corresponde à dupla de autores, com 17 publicações (37,8\%); seguido da quantidade de artigos escritos por 03 autores, com 13 publicações (28,9\%); logo após aparecem os artigos em quarteto, com 08 obras (17,8\%); os estudos escritos por apenas um autor tiveram o quantitativo de $05(11,1 \%)$; e, por fim, as pesquisas escritas por 05 pessoas tiveram o menor quantitativo, $02(4,4 \%)$. Esse resultado indica que houve muitas parcerias em projetos de pesquisa e que, grande parte delas, é fruto de colaboração entre estudantes e seus respectivos professores orientadores. Essa inferência é confirmada por meio de consulta aos dados dos autores na plataforma Lattes.

Com o intuito de identificar as bases de fundamentação dos trabalhos, foi realizado um levantamento das principais obras e autores referenciados nos estudos analisados. Observaram-se 296 obras, das quais se excluiu as referências sobre metodologia científica, sendo as principais obras, com quatro ou mais citações, apresentadas no quadro 2. 


\section{Gestãoe \\ Desenvolvimento}

e-ISSN: 2446-6875

p-ISSN: $1807-5436$

Quadro 2 - Obras mais mencionadas, seus autores e quantidade de citações

\begin{tabular}{|c|c|c|}
\hline Obras & Autor (es) & $\begin{array}{l}\text { Quantidade de } \\
\text { citações }\end{array}$ \\
\hline Liberdade de informação: um estudo de direito comparado. & Mendel, 2009 & 8 \\
\hline $\begin{array}{l}\text { Lei de Acesso à Informação e seus possíveis desdobramentos à Ac- } \\
\text { countability Democrática no Brasil }\end{array}$ & Angélico, 2012 & 7 \\
\hline $\begin{array}{l}\text { Transparência na gestão pública municipal: um estudo a partir dos } \\
\text { portais eletrônicos dos maiores municípios brasileiros }\end{array}$ & Cruz, et al., 2012 & 7 \\
\hline Accountability: já podemos traduzi-la para o português? & Pinho e Sacramento, 2009 & 7 \\
\hline $\begin{array}{l}\text { Publicidade e transparência das contas públicas: obrigatoriedade e } \\
\text { abrangência desses princípios na Administração Pública brasileira }\end{array}$ & Platt Neto, et al., 2007 & 6 \\
\hline $\begin{array}{l}\text { Investigando portais de governo eletrônico de estados no Brasil: muita } \\
\text { tecnologia, pouca democracia. }\end{array}$ & Pinho, 2008 & 5 \\
\hline $\begin{array}{c}\text { Sociedade da informação, accountability e democracia delegativa: in- } \\
\text { vestigação em portais de governo no Brasil. }\end{array}$ & Akutso e Pinho, 2002 & 5 \\
\hline $\begin{array}{c}\text { Transparência no setor público: uma análise dos relatórios de gestão } \\
\text { anuais de entidades públicas federais no ano de } 2010 .\end{array}$ & Bairral, Silva e Alves, 2015 & 4 \\
\hline Informação pública: entre o acesso e a apropriação social. & Batista, 2010 & 4 \\
\hline Accountability: quando poderemos traduzi-la para o português? & Campos, 1990 & 4 \\
\hline $\begin{array}{l}\text { Transparência da gestão pública municipal: referenciais teóricos e a } \\
\text { situação dos grandes municípios brasileiros. }\end{array}$ & Cruz, 2010 & 4 \\
\hline $\begin{array}{l}\text { O governo eletrônico no Brasil: perspectiva histórica a partir de um } \\
\text { modelo estruturado de análise }\end{array}$ & Diniz et al., 2009 & 4 \\
\hline $\begin{array}{l}\text { Prestação de contas nos portais eletrônicos de assembleias legislati- } \\
\text { vas: um estudo após a Lei de Acesso à Informação }\end{array}$ & Raupp e Pinho, 2014 & 4 \\
\hline
\end{tabular}

\section{Fonte: Elaborado pelos autores}

No que concerne aos autores, 116 foram referenciados, exceto os dos estudos de metodologia científica. Aqueles que tiveram 10 ou mais citações enquanto autores principais, à exceção dos coautores, foram: Fabiano Maury Raupp (18 citações), Robert Gregory Michener (16 citações), Jose Antonio Gomes de Pinho (15 citações), Claudia Ferreira da Cruz (14 citações), José Maria Jardim (13 citações), Toby Mendel (11 citações), Fabiano Angélico (10 citações). É importante mencionar que a maioria destes pesquisadores é composta por professores universitários que atuam na área da administração e ciências da informação.

Com o fito de melhor delinear a metodologia de elaboração das pesquisas elencadas, resumiu-se no quadro 3 os procedimentos apontados nos artigos. As classificações deles foram baseadas em uma adaptação de Vergara (2016) e Gil (2008), tendo sido apontadas apenas as classificações descritas pelos 
autores nos artigos elencados. Ressalta-se que a ordem numérica corresponde à mesma da lista de artigos estabelecida no quadro 1.

Quadro 3 - Aspectos metodológicos dos artigos estudados

\begin{tabular}{|c|c|c|c|c|c|}
\hline $\mathbf{N}^{\circ}$ & Abordagem & $\begin{array}{l}\text { Quanto aos obje- } \\
\text { tivos/fins }\end{array}$ & $\begin{array}{l}\text { Procedimentos / } \\
\text { meios de investi- } \\
\text { gação }\end{array}$ & $\begin{array}{c}\text { Técnica de inves- } \\
\text { tigação / coleta } \\
\text { de dados }\end{array}$ & Amostra \\
\hline 1 & $\begin{array}{l}\text { Não mencio- } \\
\text { nado }\end{array}$ & Não mencionado & Não mencionado & Não mencionado & Não mencionado \\
\hline 2 & $\begin{array}{l}\text { Não mencio- } \\
\text { nado }\end{array}$ & Não mencionado & Não mencionado & Não mencionado & Não mencionado \\
\hline 3 & $\begin{array}{l}\text { Não mencio- } \\
\text { nado }\end{array}$ & Não mencionado & Não mencionado & Não mencionado & Não mencionado \\
\hline 4 & $\begin{array}{l}\text { Não mencio- } \\
\text { nado }\end{array}$ & Não mencionado & Não mencionado & Não mencionado & Não mencionado \\
\hline 5 & Quantitativa & $\begin{array}{l}\text { Exploratória / } \\
\text { descritiva }\end{array}$ & $\begin{array}{c}\text { Bibliográfico / } \\
\text { documental }\end{array}$ & $\begin{array}{l}\text { Lista de verifica- } \\
\text { ção }\end{array}$ & $\begin{array}{c}\text { Sítios eletrônicos de } 30 \text { au- } \\
\text { tarquias federais }\end{array}$ \\
\hline 6 & Quantitativa & Não mencionado & Não mencionado & Checklist & $\begin{array}{c}\text { Websites de } 56 \text { municípios } \\
\text { do estado do Rio Grande do } \\
\text { Norte }\end{array}$ \\
\hline 7 & Dedutiva & Não mencionado & $\begin{array}{l}\text { Bibliográfico / } \\
\text { documental }\end{array}$ & Não mencionado & $\begin{array}{c}\text { Resoluções do Conselho } \\
\text { Nacional de Justiça }\end{array}$ \\
\hline 8 & Qualitativa & Descritivo & Observação & $\begin{array}{l}\text { Entrevista se- } \\
\text { miestruturada }\end{array}$ & $\begin{array}{c}03 \text { servidores, responsáveis } \\
\text { pelo SAC/IFRN }\end{array}$ \\
\hline 9 & $\begin{array}{l}\text { Hipotético-de- } \\
\text { dutivo }\end{array}$ & Não mencionado & Não mencionado & $\begin{array}{c}\text { Coleta de dados } \\
\text { de forma direta, } \\
\text { organizada e não } \\
\text { participativa } \\
\end{array}$ & $\begin{array}{l}\text { Página do Conselho Nacional } \\
\text { de Justiça no Facebook }\end{array}$ \\
\hline 10 & $\begin{array}{l}\text { Não mencio- } \\
\text { nado }\end{array}$ & Não mencionado & Não mencionado & Não mencionado & Não mencionado \\
\hline 11 & Qualitativa & Descritivo & $\begin{array}{l}\text { Pesquisa de le- } \\
\text { vantamento }\end{array}$ & $\begin{array}{l}\text { Protocolo de ob- } \\
\text { servação }\end{array}$ & $\begin{array}{l}27 \text { portais eletrônicos de } \\
\text { Assembleias legislativas }\end{array}$ \\
\hline 12 & $\begin{array}{l}\text { Não mencio- } \\
\text { nado }\end{array}$ & Não mencionado & $\begin{array}{l}\text { Bibliográfica / } \\
\text { Documental }\end{array}$ & Não mencionado & $\begin{array}{l}\text { Sistemática de monitora- } \\
\text { mento e avaliação de pro- } \\
\text { gramas do Plano Plurianual } \\
\text { 2008-2011 }\end{array}$ \\
\hline 13 & $\begin{array}{l}\text { Não mencio- } \\
\text { nado }\end{array}$ & Exploratória & Não mencionado & $\begin{array}{l}\text { Observação es- } \\
\text { truturada / ques- } \\
\text { tionário }\end{array}$ & $\begin{array}{c}34 \text { Controladorias-Gerais de } \\
\text { Municípios }\end{array}$ \\
\hline
\end{tabular}




\section{Gestãoe

\begin{tabular}{|c|c|c|c|c|c|}
\hline 14 & $\begin{array}{l}\text { Não mencio- } \\
\text { nado }\end{array}$ & Não mencionado & $\begin{array}{l}\text { Investigação Teó- } \\
\text { rica }\end{array}$ & $\begin{array}{l}\text { Visita / observa- } \\
\text { ção / framework } \\
\text { para análise de } \\
\text { privacidade }\end{array}$ & $\begin{array}{l}\text { Arquívo Público do estado de } \\
\text { São Paulo }\end{array}$ \\
\hline 15 & Qualitativa & Exploratória & Documental & $\begin{array}{l}\text { Protocolo de ob- } \\
\text { servação }\end{array}$ & $\begin{array}{c}75 \text { portais de legislativos } \\
\text { locais do estado de Santa } \\
\text { Catarina }\end{array}$ \\
\hline 16 & Quantitativo & Não mencionado & Não mencionado & Questionário & $\begin{array}{c}07 \text { sítios virtuais de municí- } \\
\text { pios da Região Metropolitana } \\
\text { da Grande Vitória - ES. }\end{array}$ \\
\hline 17 & Qualitativa & Descritivo & Estudo de campo & $\begin{array}{l}\text { Questionário se- } \\
\text { miestruturado / } \\
\text { entrevista }\end{array}$ & $\begin{array}{l}02 \text { servidores de um Tribunal } \\
\text { de Conta de Municípios }\end{array}$ \\
\hline 18 & $\begin{array}{c}\text { Quantitativa / } \\
\text { Qualitativa }\end{array}$ & $\begin{array}{l}\text { Exploratória / } \\
\text { descritiva }\end{array}$ & $\begin{array}{l}\text { Documentação } \\
\text { direta }\end{array}$ & $\begin{array}{l}\text { Formulário estru- } \\
\text { turado }\end{array}$ & $\begin{array}{c}40 \text { sítios virtuais de municí- } \\
\text { pios dos estados do sul do } \\
\text { Brasil }\end{array}$ \\
\hline 19 & Qualitativa & Não mencionado & $\begin{array}{l}\text { Biliográfica / Do- } \\
\text { cumental }\end{array}$ & $\begin{array}{l}\text { Levantamento de } \\
\text { informações }\end{array}$ & $\begin{array}{c}59 \text { Universidades Federais } \\
\text { brasileiras }\end{array}$ \\
\hline 20 & $\begin{array}{l}\text { Não mencio- } \\
\text { nado }\end{array}$ & Não mencionado & Não mencionado & $\begin{array}{l}\text { Estudo compa- } \\
\text { rado }\end{array}$ & $\begin{array}{c}18 \text { Estados latino-ame- } \\
\text { ricanos de origem Ibérica } \\
\text { sujeitos à jurisdição da Corte } \\
\text { Interamericana de Direitos } \\
\text { Humanos }\end{array}$ \\
\hline 21 & $\begin{array}{l}\text { Não mencio- } \\
\text { nado }\end{array}$ & Não mencionado & Não mencionado & Não mencionado & Não mencionado \\
\hline 22 & Qualitativa & Exploratória & $\begin{array}{l}\text { Estudo de caso } \\
\text { / Bibliográfica / } \\
\text { documental }\end{array}$ & $\begin{array}{l}\text { Observação parti- } \\
\text { cipante }\end{array}$ & $\begin{array}{l}\text { Universidade Federal do Rio } \\
\text { Grande do Norte }\end{array}$ \\
\hline 23 & Qualitativa & $\begin{array}{l}\text { Exploratório / } \\
\text { descritivo }\end{array}$ & Documental & Formulário & $\begin{array}{c}30 \text { sítios virtuais de muni- } \\
\text { cípios do estado de Minas } \\
\text { Gerais }\end{array}$ \\
\hline 24 & Quantitativa & Descritivo & Documental & Checklist & $\begin{array}{c}120 \text { sítios virtuais de mu- } \\
\text { nicípios do estado de Santa } \\
\text { Catarina }\end{array}$ \\
\hline 25 & Qualitativa & Descritiva & $\begin{array}{l}\text { Bibliográfica / } \\
\text { Documental }\end{array}$ & Formulário & $\begin{array}{l}216 \text { sítios virtuais de muni- } \\
\text { cípios dos estados de Santa } \\
\text { Catarina, Paraná e Rio Gran- } \\
\text { de do Sul }\end{array}$ \\
\hline 26 & Qualitativa & Descritiva & $\begin{array}{l}\text { Estudo de levan- } \\
\text { tamento }\end{array}$ & $\begin{array}{l}\text { Protocolo obser- } \\
\text { vacional }\end{array}$ & $\begin{array}{l}50 \text { Portais eletrônicos dos } \\
\text { Legislativos locais dos maio- } \\
\text { res municípios brasileiros }\end{array}$ \\
\hline
\end{tabular}




\section{Gestãoe \\ Desenvolvimento}

\begin{tabular}{|c|c|c|c|c|c|}
\hline 27 & $\begin{array}{l}\text { Não mencio- } \\
\text { nado }\end{array}$ & $\begin{array}{l}\text { Exploratório / } \\
\text { Descritiva }\end{array}$ & Bibliográfica & $\begin{array}{l}\text { Levantamento de } \\
\text { informações }\end{array}$ & $\begin{array}{c}46 \text { sítios eletrônicos de mu- } \\
\text { nicípios do Estado do Rio } \\
\text { Grande do Norte }\end{array}$ \\
\hline 28 & Qualitativo & Não mencionado & $\begin{array}{l}\text { Bibliográfica / Do- } \\
\text { cumental / Pes- } \\
\text { quisa de Campo }\end{array}$ & Relatório & $\begin{array}{c}01 \text { Instituição de Ensino } \\
\text { Superior do estado de Santa } \\
\text { Catarina }\end{array}$ \\
\hline 29 & Quantitativa & Descritiva & Documental & $\begin{array}{l}\text { Indicadores de } \\
\text { conformidade }\end{array}$ & $\begin{array}{c}40 \text { Portais da Transparência } \\
\text { de municípios do estado do } \\
\text { Rio Grande do Sul }\end{array}$ \\
\hline 30 & Quantitativa & Descritiva & Documental & $\begin{array}{c}\text { Instrumental es- } \\
\text { tatístico }\end{array}$ & $\begin{array}{c}66 \text { artigos indexados na base } \\
\text { Scopus }\end{array}$ \\
\hline 31 & $\begin{array}{l}\text { Não mencio- } \\
\text { nado }\end{array}$ & Não mencionado & Documental & Não mencionado & $\begin{array}{c}\text { Normas de disponibilização } \\
\text { de dados do Instituto Brasi- } \\
\text { leiro de Geografia e Estatísti- } \\
\text { ca (IBGE), do Instituto Nacio- } \\
\text { nal de Estudos e Pesquisas } \\
\text { Educacionais Anísio Teixeira } \\
\text { (Inep) e do Instituto de Pes- } \\
\text { quisa Econômica Aplicada } \\
\text { (Ipea) }\end{array}$ \\
\hline 32 & Qualitativa & Exploratória & $\begin{array}{l}\text { Pesquisa de } \\
\text { campo }\end{array}$ & $\begin{array}{l}\text { Entrevistas se- } \\
\text { miestruturadas }\end{array}$ & $\begin{array}{l}10 \text { gestores municipais do } \\
\text { estado do Rio Grande do Sul }\end{array}$ \\
\hline 33 & $\begin{array}{l}\text { Não mencio- } \\
\text { nado }\end{array}$ & Não mencionado & Não mencionado & Não mencionado & $\begin{array}{c}3.550 \text { solicitações de aces- } \\
\text { so à informação em todo o } \\
\text { Brasil }\end{array}$ \\
\hline 34 & $\begin{array}{l}\text { Não mencio- } \\
\text { nado }\end{array}$ & Descritiva & Documental & $\begin{array}{l}\text { Observação es- } \\
\text { truturada }\end{array}$ & $\begin{array}{l}\text { Plataformas de solicitação de } \\
\text { informação (e-SIC) de organi- } \\
\text { zações dos estados brasilei- } \\
\text { ros ( } 27 \text { governos estaduais, } \\
27 \text { assembleias legislativas e } \\
27 \text { tribunais de justiça }\end{array}$ \\
\hline 35 & $\begin{array}{l}\text { Não mencio- } \\
\text { nado }\end{array}$ & Não mencionado & Não mencionado & Não mencionado & Não mencionado \\
\hline 36 & Qualitativa & Não mencionado & $\begin{array}{l}\text { Bibliográfica / } \\
\text { Documental }\end{array}$ & Levantamento & $\begin{array}{l}09 \text { estados do nordeste } \\
\text { (regulamentação da LAl nos } \\
\text { governos estaduais) }\end{array}$ \\
\hline 37 & $\begin{array}{l}\text { Não mencio- } \\
\text { nado }\end{array}$ & Não mencionado & Não mencionado & Não mencionado & Não mencionado \\
\hline 38 & Quantitativa & Exploratória & Levantamentos & $\begin{array}{l}\text { Protocolo de ob- } \\
\text { servação }\end{array}$ & $\begin{array}{l}09 \text { portais eletrônicos das } \\
\text { Universidades e Institutos } \\
\text { Federais gaúchos }\end{array}$ \\
\hline
\end{tabular}




\section{Gestãoe \\ Desenvolvimento}

e-ISSN: 2446-6875

p-ISSN: $1807-5436$

\begin{tabular}{|c|c|c|c|c|c|}
\hline 39 & Qualitativa & $\begin{array}{c}\text { Exploratória / } \\
\text { Descritiva / Expli- } \\
\text { cativa }\end{array}$ & $\begin{array}{c}\text { Bibliográfica / } \\
\text { Documental }\end{array}$ & Não mencionado & $\begin{array}{c}\text { Relatórios de participação } \\
\text { cívica na gestão pública, } \\
\text { através da plataforma online } \\
\text { de acesso à informação ao } \\
\text { cidadão }\end{array}$ \\
\hline 40 & $\begin{array}{c}\text { Qualitativa / } \\
\text { Quantitativa }\end{array}$ & Não mencionado & Documental & Análise de portais & $\begin{array}{c}11 \text { portais dos municípios } \\
\text { pernambucanos mais popu- } \\
\text { losos }\end{array}$ \\
\hline 41 & $\begin{array}{c}\text { Qualitativa / } \\
\text { Quantitativa }\end{array}$ & $\begin{array}{c}\text { Exploratória / } \\
\text { Descritiva }\end{array}$ & $\begin{array}{c}\text { Bibliográfica / Do- } \\
\text { cumental / Estudo } \\
\text { de caso }\end{array}$ & Levantamento & $\begin{array}{c}\text { 20 sítios eletrônicos das me- } \\
\text { Ihores universidades fede- } \\
\text { rais, segundo o IGC, indicador } \\
\text { do INEP }\end{array}$ \\
\hline 42 & $\begin{array}{c}\text { Qualitativa / } \\
\text { Quantitativa }\end{array}$ & $\begin{array}{c}\text { Exploratória / } \\
\text { Descritiva }\end{array}$ & Documental & $\begin{array}{c}\text { Questionários } \\
\text { estruturados }\end{array}$ & $\begin{array}{c}\text { 01 sítio virtual da Prefeitura } \\
\text { de Londrina - PR }\end{array}$ \\
\hline 43 & $\begin{array}{c}\text { Não mencio- } \\
\text { nado }\end{array}$ & Descritiva & Bibliográfica & Levantamento & $\begin{array}{c}\text { 09 sítios virtuais das as- } \\
\text { sembleias legislativas do } \\
\text { nordeste }\end{array}$ \\
\hline Quantitativa & Descritiva & Survey & Questionário es- \\
truturado & $\begin{array}{c}38 \text { membros de Observató- } \\
\text { rios sociais de 19 estados } \\
\text { brasileiros }\end{array}$ \\
\hline
\end{tabular}

\section{Fonte: Elaborado pelos autores}

No que se refere à abordagem, o critério qualitativo teve 14 publicações $(31,1 \%)$, seguido da abordagem quantitativa, com 08 publicações $(17,8 \%)$. Houve 04 obras $(8,9 \%)$ que foram classificadas tanto como quantitativa quanto qualitativa, bem como outros 02 artigos $(4,4 \%)$ apontados como sendo de abordagem dedutiva.

Quanto aos objetivos/fins, destacam-se as pesquisas descritivas, com 11 obras (24,4\%), e as designadas como exploratórias ou como exploratórias e descritivas, ambas com 06 publicações (13,3\%). Apenas um artigo (2,2\%) teve sua finalidade entendida como exploratória/descritiva/explicativa.

Em relação aos procedimentos/meios de investigação, os estudos tiveram características bem distintas, tendo sido elencados 08 meios de investigação diferentes. Os que tiveram mais destaque foram os meios documentais, apontados individualmente por 10 publicações (22,2\%). Se observarmos que alguns autores mencionaram que sua obra teve meios de investigação justapostos, as pesquisas documentais passam a ser mencionadas em 21 obras. A segunda classificação mais relevante foi a das obras concebidas como bibliográficas e documentais, com 07 publicações $(15,6 \%$ ). 
A respeito da técnica de investigação/coleta de dados, Vergara (2016) e Gil (2008) apontaram diversas formas de colher os dados necessários aos seus estudos. A técnica mais utilizada foi a observação (estruturada ou participante), com 06 publicações (13,3\%), seguida pela técnica denominada "levantamento", com 05 publicações (11,1\%). Outros métodos de coleta relevantes foram os questionários, os formulários e as entrevistas, cada um destes esteve presente em 03 obras $(6,7 \%)$.

As amostras das investigações foram as mais variadas, as quais estão demonstradas na última coluna à direita, no quadro 4. Destacam-se grandes números de entrevistas, questionários, documentos analisados e portais eletrônicos avaliados. Em geral, os procedimentos metodológicos utilizados foram diversificados, o que pode ser compreendido pela variedade de áreas que atuam com o tema.

É relevante destacar que alguns autores não fizeram menção a algum tipo de classificação de seus procedimentos metodológicos, provavelmente pelo fato de seu artigo ter natureza teórica e não se enquadrar nas classificações propostas por Vergara (2016) e Gil (2008), ou por terem adotado a classificação de outros teóricos, que seguiam critérios distintos do estudo em tela. Estes artigos, contudo, estiveram na contabilização dos percentuais observados nos parágrafos anteriores.

No que se refere ao estabelecimento de categorização, foram observados alguns subtemas a partir da proposta de estudo dos artigos, conforme se explicita na tabela 2.

\section{Tabela 2 - Quantidade e percentual de publicações por subtema}

\begin{tabular}{cccc}
\hline Subtema & Quant. & Percent. & Artigos $^{1}$ \\
\hline Aplicação da lei na esfera do Poder Executivo Municipal & 12 & 26,7\% & $\begin{array}{c}\text { 6, 13, 16, 18, 23, 24, 25, } \\
27,29,32,40,42\end{array}$ \\
Aplicação da lei na esfera do Poder Executivo Federal & 12 & $26,7 \%$ & $\begin{array}{c}5,8,12,19,21,22,28,31, \\
38,39,41,45\end{array}$ \\
Estudos e reflexões sobre a lei e sua contribuição & 8 & $17,8 \%$ & $1,2,3,4,20,30,35,37$ \\
Atuação de órgãos que promovem a correta aplicação da lei & 5 & $11,1 \%$ & $7,9,10,17,44$ \\
Aplicação da lei na esfera do Poder Legislativo Estadual & 2 & $4,4 \%$ & 11,43 \\
Aplicação da lei na esfera do Poder Legislativo Municipal & 2 & $4,4 \%$ & 15,26 \\
Aplicação da lei na esfera do Poder Executivo Estadual & 2 & $4,4 \%$ & 14,36 \\
Aplicação da lei comparando distintas esferas de poder & 2 & $4,4 \%$ & 33,34 \\
\hline
\end{tabular}

\section{Fonte: Dados da pesquisa. Elaboração própria}

\footnotetext{
${ }^{1}$ Números conforme ordem estabelecida no Quadro 1
} 
Entre aqueles elencados no subtema "Aplicação da lei na esfera do Poder Executivo Municipal", observa-se a predominância de estudos sobre municípios localizados no Sul, Nordeste e Sudeste do país. Em nenhuma das obras foi apontado o pleno cumprimento da lei pelos poderes executivos municipais, haja vista em todos os casos haver inconformidades que, frente aos possiveis motivos, teve a falta de fiscalização como a mais apontada por diversos autores (CRUZ; SILVA; SPINELLI, 2016; BODART; TORRES; SILVA, 2015; BIANCHI; VIEIRA; KRONBAUER, 2017) e a cultura do sigilo (SANTOS; VISENTINI, 2018; AMORIM; STADLER, 2019).

No subtema "Aplicação da lei na esfera do Poder Executivo Federal", 66,7\% dos artigos voltaramse ao estudo em Instituições Federais de Ensino Superior, sendo sete de forma exclusiva, e um estudo que incluiu a análise de outras autarquias. Entre as conclusões obtidas, observou-se que, em todos os casos em que os portais eletrônicos foram analisados, não houve adequação completa à LAl. Apesar da lei e dos sistemas criados, percebeu-se necessidades de aperfeiçoamento para que os cidadãos fossem incentivados a buscar informações e que estas fossem ofertadas sem barreiras (MACIEL, et al., 2019; CARVALHO; FREITAS; BARBOSA, 2019). Entre as prováveis causas, houve menção a possivveis resistências a mudanças por parte das instituições (OLIVEIRA JÚNIOR; JORDÃO; CASTRO JUNIOR, 2016), bem como ao pouco engajamento dos agentes públicos no cumprimento da lei e de stakeholders para exercer o controle social (MELO; FUCHIGAMI, 2019).

O subtema "Estudos e reflexões sobre a lei e sua contribuição" é composto por artigos teóricos que refletiram o processo de criação, a importância e a implicação da LAl em alguns aspectos, tais como nos impasses relacionados aos arquivos da ditadura (JOFFILY, 2012) e na confidencialidade de informações pessoais nas pesquisas em saúde (VENTURA, 2013).

Os artigos listados no subtema "Atuação de órgãos que promovem a correta aplicação da lei", apontaram que o Conselho Nacional de Justiça possui boa interação com internautas em sua rede social (OLIVEIRA; RAMINELLI, 2014), mostrando atuação positiva no contexto informacional, porém, com insuficiência na transparência passiva (SILVA; HOCH; RIGHI, 2013). Houve abordagem do recente, mas significativo, papel das ouvidorias no Poder Judiciário (ROMERO; SANT'ANNA, 2014), assim como do papel de um Tribunal de Contas de Municípios (PAIVA, et al., 2015) e, por fim, o trabalho de Baldissera, et al. (2019) elucidou que os membros do Observatório Social do Brasil entendem que a qualidade das informações prestadas por portais municipais não atendem plenamente aos objetivos da LAl, todavia, têm sido úteis para fortalecer o controle social.

No que tange aos artigos elencados nos subtemas "Aplicação da lei na esfera do Poder Legislativo Estadual" e "Aplicação da lei na esfera do Poder Legislativo Municipal", todos os citados autores concluíram que havia baixa capacidade de prestação de contas e consequente baixo nível de transparência das 
Assembleias Legislativas e Câmara de Vereadores pesquisados. No subtema "Aplicação da lei na esfera do Poder Executivo Estadual", o estudo de Goncalez, Santana e Jorente (2015) comparou a privacidade dos usuários do Arquivo Público do Estado de São Paulo e verificou que, em função da adoção de recursos digitais, havia mais privacidade nos acessos. Por sua vez, a pesquisa de Barros e Medleg (2018) observou que os estados nordestinos possuíam regulamentações que contemplavam as exigências da LAl e, no caso específico do Maranhão, apesar de algumas lacunas, havia um esforço em garantir o acesso à informação.

O último subtema observado foi o de artigos que analisaram a "Aplicação da lei comparando distintas esferas de poder". Os estudos contidos nesse subtema verificaram que a implementação inconsistente da LAl é ilustrada pela escassez de indicadores de cumprimento (MICHENER; CONTRERAS; NISKIER, 2018). Drehmer e Raupp (2018) identificaram barreiras de acesso à informação nos três poderes, contudo, os resultados de sua pesquisa indicaram que os governos de estado estavam mais avançados na transparência passiva em relação aos outros dois poderes.

\section{CONSIDERAÇÕES FINAIS}

O presente estudo teve o objetivo de identificar e discutir, mediante revisão sistemática de literatura, a produção científica a respeito da Lei brasileira de Acesso à Informação publicada nas bibliotecas eletrônicas de periódicos científicos Scielo e Spell, entre os anos de 2011 e 2019. Buscou-se delinear as principais informações garimpadas de forma a traçar um panorama a respeito do tema.

Os resultados apontam que a quantidade de publicações sobre o tema proposto esteve em constante crescimento, passou a oscilar a partir do ano de 2016 e teve a maior quantidade de publicações no ano de 2018, o que denota que, apesar das oscilações, é um assunto que desperta o interesse da academia.

Além disso, é um tema que não se restringe apenas a uma área do conhecimento, tendo publicações a seu respeito em periódicos de diversos campos, com destaque para as revistas Perspectivas em Ciência da Informação, Revista do Serviço Público e Revista Desenvolvimento em Questão. No que concerne ao conceito Qualis/CAPES, a maior parte dos estudos foi publicada em revistas classificadas como B2 e B1, no campo "Administração, Ciências Contábeis e Turismo" e/ou no campo "interdisciplinar", conceitos que podem indicar artigos de qualidade intermediária e de maior qualidade, respectivamente.

Sobre a fundamentação teórica dos estudos, observou-se que buscaram embasamento em outros artigos e Dissertações com temáticas relacionadas à transparência, acesso à informação e accountability. Por sua vez, os autores mais citados foram, em sua maioria, professores universitários brasileiros, ligados à área de Administração e/ou Ciências da Informação que possuem, entre seus campos de estudo, interesse por pesquisas voltadas à democracia, transparência, controle social e prestação de contas do 
Estado. Destacam-se a quantidade de referências aos seguintes autores: Fabiano Maury Raupp; Robert Gregory Michener; Jose Antonio Gomes de Pinho; Claudia Ferreira da Cruz; José Maria Jardim; Toby Mendel e Fabiano Angélico, os quais podem ser entendidos como referências em temáticas que se interligam ao contexto da Lei 12.527/2011.

A respeito da análise metodológica, pode-se notar que existe uma grande variedade de procedimentos tomados passivel de compreensão pela diversidade de áreas e subtemas abordados. Apesar dessa pluralidade, as características mais apontadas pelos autores se referiam à utilização da abordagem qualitativa; finalidade descritiva; procedimentos documentais de investigação; como técnica de investigação/coleta de dados, a observação estruturada/participante; e amostras específicas e variadas para cada estudo realizado.

Quanto aos subtemas categorizados, destacaram-se os estudos voltados à aplicação da lei na esfera do Poder Executivo Municipal, do Poder Executivo Federal, além de obras que estudaram e refletiram sobre a lei e sua contribuição para o país, o que denota tanto a preocupação dos pesquisadores em contextualizar a lei na realidade brasileira e internacional, quanto verificar se ela está sendo cumprida nos diversos órgãos e entidades públicas.

Em geral, os estudos trouxeram reflexões da importância do surgimento e consolidação da Lei de Acesso à Informação no Estado brasileiro, todavia, evidenciaram que sua aplicabilidade, nos mais variados órgãos e distintas esferas de poder, ainda não contempla a lei em sua integralidade. Nesse sentido, o cumprimento parcial da LAI pode ser um dos motivos que levam os pesquisadores a priorizarem estudos sobre a aplicabilidade da lei em sítios virtuais específicos, o que pode estar ocasionando escasso debate sobre a evolução do acesso à informação no Brasil, já que o mínimo que a lei propõe não vem sendo efetivamente colocado em prática por parte das diversas entidades públicas.

Frente a essa realidade, o acesso à informação se revela como campo com grande possibilidade de exploração. Sugere-se, então, no intuito de enriquecer e aprofundar a agenda de pesquisa acadêmica, buscar compreender e mensurar a efetividade da atuação dos órgãos de controle, cortes de contas e do judiciário para garantir o direito à informação da população; identificar a compreensão e a ação da alta gestão dos órgãos governamentais sobre o acesso à informação, de forma a traçar um paralelo com seu resultado prático; compreender como ocorre o processo de construção dos sítios virtuais e como acontece seu gerenciamento de informações; analisar a perspectiva do público, suas dificuldades e sua avaliação da condição de acesso e das informações dispostas; estabelecer proposituras e/ou modelos no que se refere aos sítios virtuais e aos regulamentos sobre o acesso à informação dos órgãos públicos, de forma a contribuir para a melhor execução da lei. Esses e diversos outros objetivos podem ser almejados para o enriquecimento da pesquisa científica. 
Compreende-se que a temática abordada é relevante, possui condições de ser aprofundada e tem sido discutida por autores de variados campos do conhecimento, tornando-se imperativo que os pesquisadores desenvolvam estudos similares e complementares e acompanhem a aplicação da LAI no Brasil, de forma a contribuir com a sociedade na disponibilização e análise de dados relativos ao acesso à informação e na consequente promoção da transparência e accountability.

Destarte, sugere-se que análises sistemáticas futuras possam superar as limitações presentes nesta, com vistas a agregar outras fontes, tais como anais de eventos científicos, Dissertações e Teses defendidas, bem como outras bases de dados, como a Web of Science, ou mesmo outros métodos e técnicas de análise de forma a avançar na discussão da temática.

\section{REFERÊNCIAS}

ABRUCIO, F. L.; LOUREIRO, M. R. Finanças públicas, democracia e accountability. In: ARVATE, P. R.; BIDERMAN, C. (Org.). Economia do setor público no Brasil. Rio de Janeiro: Elsevier, 2004. p. 75-102. Disponível em: https://pesquisa-eaesp.fgv.br/publicacoes/gvp/financas-publicas-democracia-e-instrumentos-de-accountability. Acesso em: 21 nov. 2019.

AMORIM, F. B.; STADLER, A. O acesso à informação na gestão pública: dificuldades enfrentadas pelo poder executivo municipal de Londrina/PR. Revista de Gestão e Secretariado, [S.I.], v. 10, n. 2, p. 246 268, ago. 2019. ISSN 2178-9010. Disponivel em: https://www.revistagesec.org.br/secretariado/article/ view/873. Acesso em: 21 nov. 2019.

ANGÉLICO, F. Lei de Acesso à Informação e seus possíveis desdobramentos à Accountability Democrática no Brasil. 2012. 133 f. Dissertação (Mestrado em Administração Pública e Governo) - Fundação Getúlio Vargas, São Paulo, 2012.

AKUTSU, L.; PINHO, J. A. G. de. Sociedade da informação, accountability e democracia delegativa: investigação em portais de governo no Brasil. Revista de Administração Pública, Rio de Janeiro, RJ, v. 36, n. 5, p. 723-745, set./out. 2002. Disponivel em: http://bibliotecadigital.fgv.br/ojs/index.php/rap/article/ view/6461/5045. Acesso em: 25 nov. 2019.

BAIRRAL, M. A. da C.; SILVA, A. H. C. e; ALVES, F. J. dos S. Transparência no setor público: uma análise dos relatórios de gestão anuais de entidades públicas federais no ano de 2010. Revista de Administração Pública, Rio de Janeiro, v. 49, n. 3, p. 643-675, jun. 2015. Disponivel em: http:// www.scielo.br/scielo. php?script=sci_arttext\&pid=S0034-6122015000300643\&lng=pt\&nrm=iso. Acesso em: 27 nov. 2019. 
BALDISSERA, J.; WALTER, S.; FIIRST, C.; ASTA, D. A Percepção dos Observatórios Sociais sobre a Qualidade, Utilidade e Suficiência da Transparência Pública dos Municípios Brasileiros. Sociedade, Contabilidade e Gestão, v. 14, n.1, 11 fev. 2019. Disponivel em: https://revistas.ufrj.br/index.php/scg/article/ view/18404. Acesso em: 20 nov. 2019.

BARATA, R. B. Dez coisas que você deveria saber sobre o Qualis. Revista Brasileira de Pós-Graduação, Brasília, v. 13, n. 30, p. 13-40, 22 dez. 2016. Disponivel em: http://ojs.rbpg.capes.gov.br/index.php/rbpg/ article/view/947. Acesso em: 25 nov. 2019.

BARROS, D. S.; MEDLEG, G. R. Acesso à informaç̧ão na região nordeste: balanço da criação da LAI nos estados e o processo de sua regulamentação no Maranhão. Perspect. ciênc. inf., Belo Horizonte, v. 23, n. 1, p. 2-18, jan. 2018. Disponivel em: http:/www.scielo.br/scielo.php?script=sci_arttext\&pid=S1413-99362018000100002\&lng=en\&nrm=iso. Acesso em: 21 nov. 2019.

BATISTA, C. L. Informação pública: entre o acesso e a apropriação social. 2010. Dissertação (Mestrado em Ciência da Informação) - Escola de Comunicações e Artes. Universidade de São Paulo, São Paulo, 2010. Disponível em: http://www.teses.usp.br/teses/disponiveis/27/27151/tde-05112010-110124/ pt-br.php. Acesso em: 30 nov. 2019.

BIANCHI, M.; VIEIRA, E.; KRONBAUER, C. Análise do Grau de Aderência à Lei de Responsabilidade Fiscal e à Lei de Acesso à Informação nos Municípios do Estado do Rio Grande do Sul com Mais de 50 Mil Habitantes. Desenvolvimento em Questão, v. 15, n. 41, p. 131-163, 21 out. 2017. Disponível em: https:// www.revistas.unijui.edu.br/index.php/desenvolvimentoemquestao/article/view/5700. Acesso em: 22 nov. 2019.

BODART, C. das N.; TORRES, K. R.; SILVA, R. S. Avaliação de sítios municipais da Região Metropolitana da Grande Vitória-ES. Cadernos Gestão Pública e Cidadania, [S.I.], v. 20, n. 66, jan. 2015. ISSN 2236-5710. DOI: http://dx.doi.org/10.12660/cgpc.v20n66.45455. Disponivel em: http://bibliotecadigital.fgv.br/ojs/ index.php/cgpc/article/view/45455. Acesso em: 22 nov. 2019.

BRASIL. [Constituição (1988)]. Constituição da República Federativa do Brasil de 1988. Brasília, DF: Presidência da República, [2016]. Disponivel em: http://www.planalto.gov.br/ccivil_03/constituicao/ constituicao.htm. Acesso em: 21 nov. 2019.

BRASIL. Lei $\mathbf{n}^{\mathbf{1}} \mathbf{1 2 . 5 2 7}$, de 18 de novembro de 2011. Regula o acesso a informações previsto no inciso XXXIII do art. 50, no inciso II do $\S 3^{\circ}$ do art. 37 e no $\S 2^{\circ}$ do art. 216 da Constituição Federal; altera a Lei $n^{\circ}$ 8.112, de 11 de dezembro de 1990; revoga a Lei n 11.111, de 5 de maio de 2005, e dispositivos da Lei n 8.159, de 8 de janeiro de 1991; e dá outras providências. Brasilia: Presidência da República [2011]. 
Disponivel em: http://www.planalto.gov.br/ccivil_03/_ato2011-2014/2011/lei//12527.htm. Acesso em: 21 nov. 2019.

CAMPOS, A. M. Accountability: quando poderemos traduzi-la para o português? Revista de Administração Pública, v. 24, n. 2, p. 30-50, fev./abr. 1990. Disponivel em: http://bibliotecadigital.fgv.br/ojs/index. php/rap/article/view/9049. Acesso em 19 nov. 2019.

CARNIELLO, M. F.; SANTOS, M. J. dos; OLIVEIRA, E. A. de A. Q. Uso de ferramentas de comunicação digital na gestão de municípios das capitais brasileiras. Revista Gestão e Desenvolvimento, [S. I.], v. 8, n. 1, 2011. DOI: 10.25112/rgd.v8i1.979. Disponível em: https://periodicos.feevale.br/seer/index.php/revistagestaoedesenvolvimento/article/view/979. Acesso em: 10 ago. 2021.

CARVALHO, I. C. S de; FREITAS, K. A.; BARBOSA, C. R. Tecnologia da informação como apoio à participação social. Pretexto, v. 20, n 3, p. 55-67, jul. a set., 2019. Disponível em: http://www.fumec.br/revistas/ pretexto/article/view/6027. Acesso em: 22 nov. 2019.

CRESWELL, J. W. Projeto de pesquisa: métodos qualitativo, quantitativo e misto. 2. ed. Porto Alegre: Artmed, 2007.

CRUZ, C. F. Transparência da gestão pública municipal: referenciais teóricos e a situação dos grandes municípios brasileiros. 2010. Dissertação (Mestrado em Ciências Contábeis), Universidade Federal do Rio de Janeiro. Disponível em: http://www.dominiopublico.gov.br/pesquisa/DetalheObraForm.do?select_action=\&co_obra=172423. Acesso em: 25 nov. 2019.

CRUZ, M. do C. M. T.; SILVA, T. A. B.; SPINELLI, M. V. O papel das controladorias locais no cumprimento da Lei de Acesso à Informação pelos municípios brasileiros. Cad. EBAPE.BR, Rio de Janeiro, v. 14, n. 3, p. 721-743, set. 2016.

Disponivel em: http://www.scielo.br/scielo.php?script=sci_arttext\&pid=S1679-39512016000300721\&lng=en\&nrm=iso. Acesso em: 20 nov. 2019.

CRUZ, C. F.; FERREIRA, A. C. S.; SILVA, L. M.; MACEDO, M. A. S. Transparência na gestão pública municipal: um estudo a partir dos portais eletrônicos dos maiores municípios brasileiros. Revista de Administração Pública, v. 46, n. 1, p. 153-176, 2012. Disponível em: https://doi.org/10.1590/S003476122012000100008. Acesso em: 02 dez. 2019.

DINIZ, E. H.; BARBOSA, A. F.; JUNQUEIRA, A. R. B.; PRADO, O. O governo eletrônico no Brasil: perspectiva histórica a partir de um modelo estruturado de análise. Revista de Administração Pública, v. 43, n. 1, p. 
23-48, 2009. Disponivel em: https://bibliotecadigital.fgv.br/ojs/index.php/rap/article/view/6678. Acesso em: 29 nov. 2019.

DREHMER, A.; RAUPP, F. M. Comparando Transparência Passiva na esfera estadual: Executivo, Legislativo e Judiciário. Sociedade, Contabilidade e Gestão, v. 13, n. 2, p. 28-46. 28 ago. 2018. DOI: https:// doi.org/10.21446/scg_ufrj.v13i2.13673. Disponivel em: https://revistas.ufrj.br/index.php/scg/article/ view/13673. Acesso em: 21 nov. 2019.

GALVÃO, T. F.; PEREIRA, M. G. Revisões sistemáticas da literatura: passos para sua elaboração. Epidemiol. Serv. Saúde, Brasilia, v. 23, n. 1, p. 183-184, mar. 2014. Disponível em: http://scielo.iec.gov. br/scielo.php?script=sci_arttext\&pid=S1679-49742014000100018\&lng=pt\&nrm=iso. Acesso em: 02 dez. 2019.

GIL, A. C. Como elaborar projetos de pesquisa. 6. ed. São Paulo: Atlas, 2008.

GONCALEZ, P. R. V. A.; SANTANA, R. C. G.; JORENTE, M. J. V. Privacidade do usuário na atividade de busca: o caso do Arquivo Público do Estado de São Paulo. Perspect. ciênc. inf., Belo Horizonte, v. 20, n. 3, p. 137-151, Set. 2015. DOI: http://dx.doi.org/10.1590/1981-5344/2372. Disponivel em: http://scielo. iec.gov.br/scielo.php?script=sci_arttext\&pid=S1679-49742014000100018\&Ing=pt\&nrm=iso. Acesso em: 24 nov. 2019.

JARDIM, J. M. A lei de acesso à informação pública: dimensões político-informacionais. Tendências da Pesquisa Brasileira em Ciência da Informação, v. 5, n. 1, 2012. Disponível em: http://hdl.handle. net/20.500.11959/brapci/119450. Acesso em: 21 nov. 2019.

JOFFILY, M. Direito à informação e direito à vida privada: os impasses em torno do acesso aos arquivos da ditadura militar brasileira. Revista Estudos Históricos, Rio de Janeiro, v. 25, n. 49, p. 129-148, jul. 2012. ISSN 2178-1494. Disponivel em: http://bibliotecadigital.fgv.br/ojs/index.php/reh/article/ view/3766. Acesso em: 21 nov. 2019.

MACIEL, R. G.; FONSECA, P. G.; DUARTE, F. R.; SANTOS, E. M. Sistema Eletrônico do Serviço de Informação ao Cidadão (e-SIC) e sua contribuição para a transparência: uma experiência gerencial em uma universidade federal. Perspect. ciênc. inf., Belo Horizonte, v. 24, n. 2, p. 143-164, jun. 2019. DOl: http:// dx.doi.org/10.1590/1981-5344/3824. Disponivel em: http://www.scielo.br/scielo.php?script=sci_arttext\&pid=S1413-99362019000200143\&Ing=en\&nrm=iso. Acesso em: 21 nov. 2019.

MELO, D. A.; FUCHIGAMI, H. Y. Proposta de índice bidimensional de transparência da informação público-eletrônica como ferramenta para participação e controle sociais. Revista Eletrônica de Administração, 
[S.I.], v. 25, n. 2, p. 179-214, ago. 2019. ISSN 1413-2311. Disponível em: https://seer.ufrgs.br/read/article/view/91523. Acesso em: 22 nov. 2019.

MENDEL, T. Liberdade de informação: um estudo de direito comparado. 2. ed. .2009. 172p. Brasília: UNESCO. Disponível em: http://unesdoc.unesco.org/images/0015/001584/158450por.pdf. Acesso em: 25 nov. 2019.

MICHENER, G.; CONTRERAS, E.; NISKIER, I. Da opacidade à transparência? Avaliando a Lei de Acesso à Informação no Brasil cinco anos depois. Revista de Administração Pública, Rio de Janeiro, v. 52, n. 4, p. 610-629, jul. 2018. ISSN 1982-3134. Disponível em: http://bibliotecadigital.fgv.br/ojs/index.php/rap/article/view/75716. Acesso em: 21 nov. 2019.

OLIVEIRA, R. S. de; RAMINELLI, F. P. O direito ao acesso à informação na construção da democracia participativa: uma análise da página do conselho nacional de justiça no facebook. Sequência (Florianópolis), Florianópolis, n. 69, p. 159-182, dez. 2014. DOI: http://dx.doi.org/10.5007/ 2177-7055.2014v35n69p159. Disponivel em: http://www.scielo.br/scielo.php?script=sci_arttext\&pi$\mathrm{d}=\mathrm{S} 2177-70552014000200007 \& \operatorname{lng}=e n \& n r m=i s o$. Acesso em: $21 \mathrm{dez} .2019$.

OLIVEIRA JÚNIOR, T. M.; JORDÃO, C.; CASTRO JUNIOR, J. Planejamento Governamental e Acesso à Informação no Brasil: Lacunas, Complementariedade e Mudança Institucional. Revista Administração em Diálogo - RAD, [S.I.], v. 18, n. 1, p. 112-132, jan. 2016. ISSN 2178-0080. Disponível em: http://revistas. pucsp.br/rad/article/view/rad.v18i1.15766. Acesso em: 23 nov. 2019.

PAIVA, J. M.; RABELO, J. V. B. F.; BIZARRIA, F. P. A.; BRASIL, M. V. O.; TASSIGNY, M. M. Análise normativa da transparência em um tribunal de contas dos municípios. Amazônia, organizações e sustentabilidade, v. 4, n. 2, 2015. Disponivel em: http://revistas.unama.br/index.php/aos/article/view/333. Acesso em: 21 nov. 2019.

PAPENFUB, U.; SCHAEFER, C. Improving public accountability by aligning reporting to organizational changes in public service provision - an empirical Internet study of all Austrian, German and Swiss towns and states from an agency-theory perspective. International Review of Administrative Sciences, v. 76, n. 3, p. 555-576, set. 2010. DOl: https://doi.org/10.1177/0020852310372451. Disponivel em: https:// journals.sagepub.com/doi/abs/10.1177/0020852310372451. Acesso em: 21 nov. 2019

PINHO, J. A. G. Investigando portais de governo eletrônico de estados no Brasil: muita tecnologia, pouca democracia. Revista de Administração Pública, Rio de Janeiro, ano 42, n. 3, p.471-493, maio/jun. 2008. Disponível em: https://doi.org/10.1590/S0034-76122008000300003. Acesso em: 21 nov. 2019. 
PINHO, J. A. G. de; SACRAMENTO, A. R. S. Accountability: já podemos traduzi-la para o português? Revista de Administração Pública, Rio de Janeiro, v. 43, n. 6, p. 1343-1368, nov./dez. 2009. Disponível em: http://www.scielo.br/pdf/rap/v43n6/06.pdf. Acesso em: 24 nov. 2019.

PLATT NETO, O. A.; CRUZ, F. da; ENSSLIN, S. R.; ENSSLIN, L. Publicidade e transparência das contas públicas: obrigatoriedade e abrangência desses princípios na Administração Pública brasileira. Contabilidade Vista \& Revista, Belo Horizonte, MG, v. 18, n. 1, p. 75-94, jan./mar. 2007. Disponível em: https://revistas. face.ufmg.br/index.php/contabilidadevistaerevista/article/view/320/313. Acesso em: 20 nov. 2019.

RAUPP, F. M.; PINHO, J. A. G. de. Prestação de contas nos portais eletrônicos de assembleias legislativas: um estudo após a Lei de Acesso à Informação. Revista Gestão e Planejamento, Salvador, BA, v. 15, n. 1, p. 144-161, jan./abr. 2014. Disponivel em: https://revistas.unifacs.br/index.php/rgb/article/view/2411. Acesso em: 25 nov. 2019.

RICHARDSON, R. J. Pesquisa Social: métodos e técnicas. 3. ed. revista e ampliada. São Paulo: Atlas, 2012.

ROMERO, H. H.; SANT'ANNA, F. C. C. M. O papel das ouvidorias na comunicação pública do Poder Judiciário. Revista do Serviço Público, v. 65, n. 2, p. p. 185-198, 24 jun. 2014. Disponível em: https://revista. enap.gov.br/index.php/RSP/article/view/579. Acesso em: 22 nov. 2019.

ROSA, M. M.; BERNARDO, F. D.; VICENTE, E. F. R.; PETRI, S. M. A Lei de Acesso à Informação como instrumento de controle social: Diagnóstico dos Municípios do Sul do Brasil à Luz do Artigo $8^{\circ}$ da Lei 12527/2011. NAVUS - Revista de Gestão e Tecnologia, v. 6, n. 1, p. 72-87, 2016. Disponível em: http:// navus.sc.senac.br/index.php/navus/article/view/359. Acesso em: 22 nov. 2019.

SAMPAIO, R. F.; MANCINI, M. C. Estudos de revisão sistemática: um guia para síntese criteriosa da evidência científica. Rev. bras. fisioter., São Carlos, v. 11, n. 1, p. 83-89, fev. 2007. Disponível em: http:// www.scielo.br/scielo.php?script=sci_arttext\&pid=S1413-35552007000100013\&lng=en\&nrm=iso. Acesso em: 02 dez. 2019.

SANTOS, M. dos; VISENTINI, M. S. Elaboração de um ranking da transparência e compreensão das práticas de gestão de municípios integrantes do COREDE Missões-RS. Administração Pública e Gestão Social, Viçosa, MG, p. 239-247, out. 2018. Disponível em: https://periodicos.ufv.br/apgs/article/view/5634. Acesso em: 22 nov. 2019.

SILVA, R. L. da; HOCH, P. A.; RIGHI, L. M. Transparência pública e a atuação normativa do CNJ. Revista Direito GV, [S.I.], v. 9, n. 2, p. 489-514, jul. 2013. ISSN 2317-6172. Disponível em: http://bibliotecadigital. fgv.br/ojs/index.php/revdireitogv/article/view/21440. Acesso em: 21 nov. 2019. 
SILVA, T. E. da; EIRÃO, T. G.; CAVALCANTE, R. S. Acesso à Informação: notas de pesquisa. Informação \& Informação, [S.I.], v. 18, n. 2, p. 01-19, ago. 2013. ISSN 1981-8920. Disponivel em: http://www.uel.br/ revistas/uel/index.php/informacao/article/view/16125. Acesso em: 21 nov. 2019.

SILVA NETO, J. H.; CARVALHO, J. R. M.; SILVA, E. E. D.; CARVALHO, E. K. M de A. Transparência Fiscal dos Municípios Mais Populosos do Estado de Pernambuco. Teoria e Prática em Administração. v. 9, n. 2, p. 64-76, 2019. Disponivel em: https:/periodicos.ufpb.br/ojs2/index.php/tpa/article/view/42178. Acesso em: 21 nov. 2019.

TRANFIELD, D.; DENYER, D.; SMART, P. Towards a methodology for developing evidence-informed management knowledge by means of systematic review. British Journal of Management, v. 14, n. 3, p. 207222, 2003. Disponível em: https://onlinelibrary.wiley.com/doi/abs/10.1111/1467-8551.00375. Acesso em: 21 abr. 2020.

VENTURA, M. Lei de acesso à informação, privacidade e a pesquisa em saúde. Cad. Saúde Pública, Rio de Janeiro, v. 29, n. 4, p. 636-638, abr. 2013. Disponível em: http://www.scielo.br/scielo.php?script=sci_arttext\&pid=S0102-311X2013000400002\&lng=en\&nrm=iso. Acesso em: 20 nov. 2019.

VERGARA, S. C. Projetos e Relatórios de Pesquisa em Administração. 16. ed. São Paulo: Atlas, 2016.

VIANNA JUNIOR, A. J. D. O.; ABREU, J. C. A. de; RAMOS, E. M. dos S. R.; BERNARDES, S. A. P. Contribuições da Lei de Acesso à Informação para o avanço da transparência no Brasil. Revista Gestão e Desenvolvimento, [S. I.], v. 16, n. 3, p. 134-152, 2019. DOI: 10.25112/rgd.v16i3.1778. Disponivel em: https://periodicos.feevale.br/seer/index.php/revistagestaoedesenvolvimento/article/view/1778. Acesso em: 10 ago. 2021.

VISENTINI, M.; SANTOS, M. Transparência na Gestão Pública Municipal Evidenciada nos Portais Eletrônicos dos Municípios do Conselho Regional de Desenvolvimento (Corede) das Missões/RS. Desenvolvimento em Questão, v. 17, n. 49, p. 158-175, 17 out. 2019. Disponível em: https://www.revistas.unijui. edu.br/index.php/desenvolvimentoemquestao/article/view/8082. Acesso em: 21 nov. 2019. 